\title{
343 電動機の積層固定子鉄心の固有振動数解析
}

Natural Frequency Analysis of Motor Laminated Core

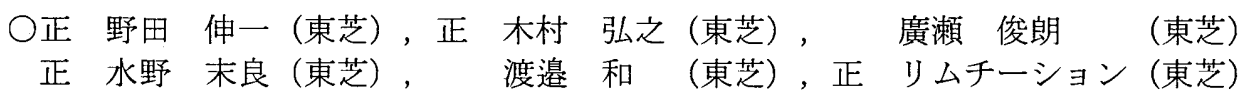

Shinichi NODA, Toshiba Corporation, 1, Toshiba-cho, Fuchu-shi, Tokyo

Hiroyuki KIMURA, Toshiba Corporation

Toshiaki HIROSE, Toshiba Corporation

Sueyoshi MIZUNO, Toshiba Corporation

Urara WATANABE, Toshiba Corporation

LIM Chee Siong, Toshiba Corporation

\begin{abstract}
Increasing interest in environmental matters, quite motors are drastically demanded lately. Among of acoustic noise of the motor, electromagnetic acoustic noise is jarring and is studied recently. Electromagnetic acoustic noise is strongly affected by (1) increase of magnetic density by reduction of motor size and (2) decrease of stiffness by saving weight. In order to reduce electromagnetic acoustic noise, it is necessary to design the motors of which natural frequencies do not coincide with electromagnetic force frequencies. In order to avoid the resonance of the natural frequencies of the core and the electromagnetic force frequencies at design phase, machine designers should predict these frequencies accurately. In this paper, vibration modes and natural frequencies of thick cylinder are studied by experiments and Finite Element analyses.
\end{abstract}

Key Words: Motors, Laminated core, Natural frequency, Electromagnetic acoustic noise, FEM

\section{A1. 緒 言}

環境問題への関心の高まりから, 近年, 電動機の騒音低 減が強く求められている. その中でも電磁騒音は，電動機 の騒音の中でも耳障りな騒音として, 特に問題にされてい る. 電磁騒音の要因としては, (1)電動機の小形化設計に よる磁束密度の増加や，（2）軽量化による構造上の剛性低 下の影響が大きい. 電磁騒音の起因となる加振力は, 固定 子鉄心と回転子鉄心間に働く電磁力の高調波である．最近 では, インバータによる可変周波数駆動式が増加している ため，固定子鉄心と回転子鉄心の間に働く電磁力の周波数 範囲が広がり，電磁力の周波数と構造物の固有振動数が一 致もしくは近接して著しい騒音が発生する場合が多くなっ ている.

しかし，固定子鉄心の積層構造まで含めた三次元モデル による固有振動数解析の研究はほとんど見当らず, 積層構 造の振動モードおよび固有振動数が実験により測定されて いるのみである. 本研究では, 電動機の電磁騒音低減を 目的として，積層構造の固定子鉄心の固有振動数を精度 良く予測する手法開発の一環として，厚肉円筒の固有振 動数や振動モードに及ぼす円筒の長さや軸方向の繸弾性 係数の影響ついて検討する。

\section{A2. 結 果}

（1）等方性の厚肉円筒モデルについて，打慗試験およ びF E M解析を行い，楕円モード（同相，逆相），三角 形モード（同相，逆相）の固有振動数を求め, 雨者が誤 差 $3 \%$ 以内で一致することを確認した.

(2) 厚肉円筒モデルの同相モードの固有振動数は軸方 向長さにはほとんど依存しないが，逆相モードの固有振 動数は，長くなるほど低下することを示した。

（3）厚肉円筒モデルの軸方向の縦弹性係数を变化させた 場合のF EM解析を行い, 同相モードの固有振動数は軸方 向の縦弾性係数には依存しないが，逆相モードの固有振動 数は軸方向の縦弾性係数が小さくなるほど低下することを 示した

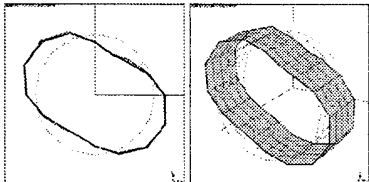

(a) $2219 \mathrm{~Hz}(\operatorname{Exp}$.
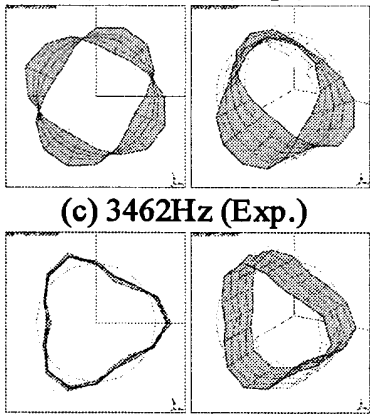

(e) $6067 \mathrm{~Hz}($ Exp.) (c) $3462 \mathrm{~Hz}($ Exp.)

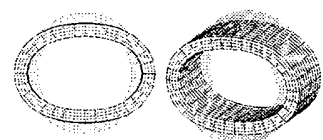

(b) $2263 \mathrm{~Hz}$ (FEM)

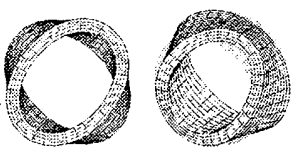

(d) $3489 \mathrm{~Hz}$ (FEM)

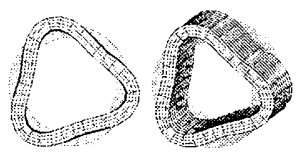

(f) $6224 \mathrm{~Hz}$ (FEM)
Fig. A1 Vibration mode and natural frequency of isotropic thick cylinder $(\mathrm{L}=66 \mathrm{~mm})$

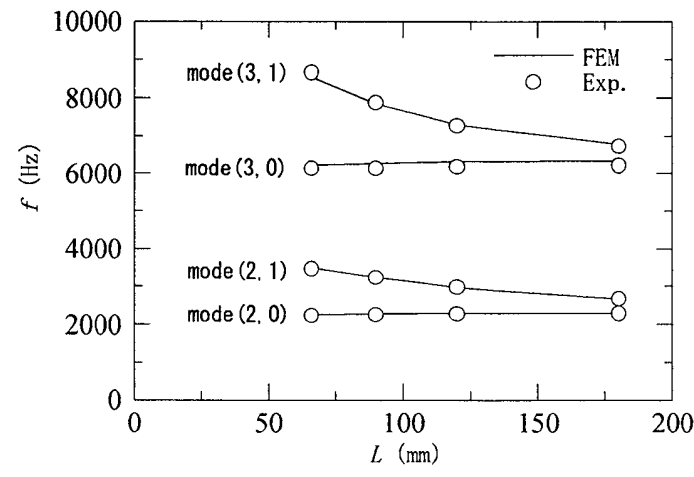

Fig. A2 Effect of cylinder length on natural frequency of isotropic thick cylinder 


\section{1. 緒 言}

環境問題への関心の高まりから, 近年, 電動機の騒音 低減が強く求められている，その中でも電磁騒音は，電 動機の騒音の中でも耳障りな騷音として，特に問題にさ れている，電磁騒音の要因としては，(1) 電動機の小形 化設計による磁束密度の増加や，（2）軽量化による構造 上の剛性低下の影響が大きい，電磁騒音の起因となる加 振力は，固定子鉄心と回転子鉄心間に働く電磁力の高調 波である. 最近では，インバータによる可変周波数駆動 式が増加しているため，固定子鉄心と回転子鉄心の間に 働く電磁力の周波数範囲が広がり，電磁力の周波数と構 造物の固有振動数が一致もしくは近接して著しい騒音が 発生する場合が多くなっている(1).

しかし，固定子鉄心の積層構造まで含めた三次元モデ ルによる固有振動数解析の研究はほとんど見当らず，積 層構造の振動モードおよび固有振動数が実験により測定 されているのみである.このような積層された固定鉄心 の振動解析をする上で，以下の課題がある.

（1）積層構造の固定子鉄心を軸方向の縦弾性係数が小 さい異方性材料として扱うことで，振動モ一ドおよび固 有振動数を F E M 解析で推定できることを前報 (2) で示 した。また，積層方向の等価縦弾性係数は電磁鋼板の約 1/10 であることを示したが，この等価縦弾性係数は積層 方法（カシメ，溶接）に依存する可能性がある.

（2）厚肉円筒の振動モードや固有振動数についての理 論解 (3) が示されているが，軸方向に積層された構造に 関する理論解は得られていない.

本研究では, 電動機の電磁騒音低減を目的として, 積 層構造の固定子鉄心の固有振動数を精度良く予測する手 法開発の一環として，厚肉円筒の固有振動数や振動モー ドに及ぼす円筒の長さや軸方向の縦弾性係数の影響つい て検討する.

\section{2. 実 験 方 法}

$2 \cdot 1$ 供試モデル 図 1 に示す厚肉円筒モデルを用い る.モデルの寸法は中形電動機の中で最も生産量の多い 標準の誘導電動機の固定子鉄心の寸法を参考に決定した. モデルの外径 $\phi 145 \mathrm{~mm}$, 内径 $\phi 115 \mathrm{~mm}$ であり, 軸方向の長 さ $L$ は $66,90,120$ および $180 \mathrm{~mm}$ とした.

固定子鉄心は，厚さ $0.35 \mathrm{~mm}$ の電磁鋼板をプレス機械 で連続打ち抜きにより鉄心形状に成形され，カシメによ り締結しているが，本供試モデルは SS 材から削り出して 製作した.

$2 \cdot 2$ 実験方法 供試円筒モデルの固有振動数を測定す るため，実験モーダル解析を行った．図 2 に振動測定の ブロックダイヤグラムを示す. 固有振動数と振動モード
の測定に際して, 供試モデルは, 厚さ $100 \mathrm{~mm}$ のウレタン ゴム上に弾性支持し，外部からの振動伝達と振動挙動に 影響がないように配慮した。

\section{3. 解 析 方 法}

固定子鉄心は，電磁鋼板の積層構造であり，前報 (2) では, 電磁鋼板の積層構造を軸方向の縦弾性係数が電磁 鋼板面内の約 $1 / 10$ である三次元直交異方性体として扱え ることを示した.

$3 \cdot 1$ 等方性モデル 今回, 実験を行う厚肉円筒モデル の振動モードおよび固有振動数を解析するため, 三次元 の等方性立体要素 (周方向 32 分割, 長手方向 10 分割, 厚さ方向 4 分割) を用いる. 固有振動数に及ぼすモデル 長さの影響について検討する.

$3 \cdot 2$ 異方性モデル 前報 ${ }^{(2)}$ と同様に軸方向の縦弾性 係数をパラメータとして変化させて振動モードおよび固 有振動数を解析し, 軸方向の縦弾性係数が固有振動数に 及ぼす影響について検討する。

異方性主軸のそれぞれの縦弾性係数を $\mathrm{E} ， \mathrm{E}^{\prime}$ ，横弾 性係数を $\mathrm{G}, \mathrm{G}^{\prime}$ ' ポアソン比を $v, v^{\prime}$, とする. 表 1 に解析に用いた物性值を示す.ひずみ $\varepsilon$ と応力 $\sigma$ と の関倸は式 (1)，（2）で表すことができる.

$$
\begin{aligned}
\{\varepsilon\} & =[\mathrm{C}] \cdot\{\sigma\} \\
{[\mathrm{C}] } & =\left[\begin{array}{cccccc}
1 / \mathrm{E} & -v / \mathrm{E} & -v^{\prime} / \mathrm{E}^{\prime} & 0 & 0 & 0 \\
-v / \mathrm{E} & 1 / \mathrm{E} & -v^{\prime} / \mathrm{E}^{\prime} & 0 & 0 & 0 \\
-v^{\prime} / \mathrm{E}^{\prime} & -v^{\prime} / \mathrm{E}^{\prime} & 1 / \mathrm{E}^{\prime} & 0 & 0 & 0 \\
0 & 0 & 0 & 1 / \mathrm{G}^{\prime} & 0 & 0 \\
0 & 0 & 0 & 0 & 1 / \mathrm{G}^{\prime} & 0 \\
0 & 0 & 0 & 0 & 0 & 1 / \mathrm{G}
\end{array}\right]
\end{aligned}
$$

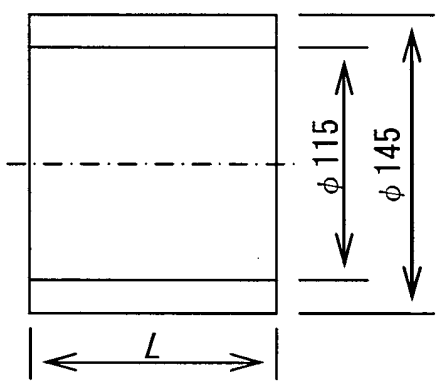

Fig. 1 Tested thick cylinder $(L=66,90,120$ and $180 \mathrm{~mm})$

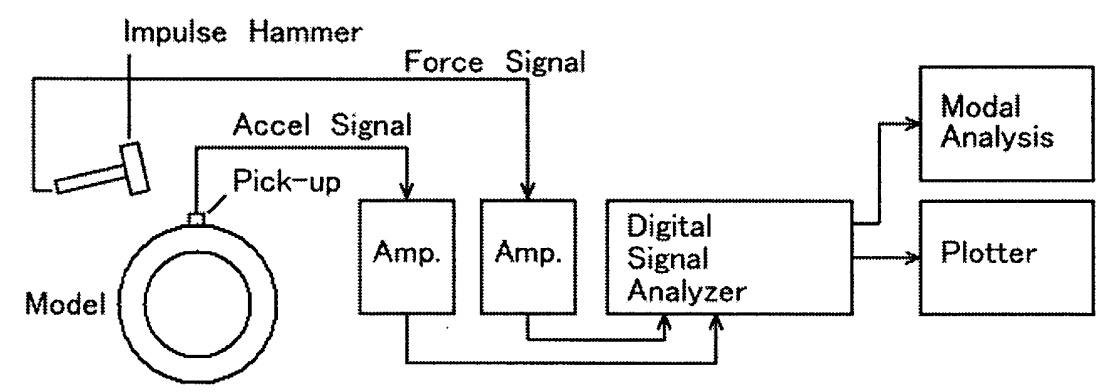

Fig. 2 Block diagram of vibration measur ement system 
Table 1 Constant values used in analyses

\begin{tabular}{|c|c|}
\hline \multicolumn{2}{|c|}{ Young's Modulus (GPa) } \\
\hline $\mathrm{E}$ & 205.8 \\
\hline $\mathrm{E}^{\prime}$ & $0.08 \mathrm{E} \sim 1.0 \mathrm{E}$ \\
\hline \multicolumn{2}{|c|}{ Poisson's Ratio } \\
\hline$v$ & 0.30 \\
\hline$v^{\prime}$ & 0.01 \\
\hline \multicolumn{1}{|c|}{ Shear Modulus (GPa) } \\
\hline$G \quad$ & $\mathrm{E} / 2(1+v)=79.2$ \\
\hline $\mathrm{G}^{\prime}$ & $\mathrm{E}^{\prime} / 2\left(1+v^{\prime}\right)$ \\
\hline
\end{tabular}

\section{4. 結果および考察}

$4 \cdot 1$ 周波数応答関数 図 3 , 図 4 に打撃試験で得られ た周波数応答関数（F R F）の一例を示す. 図 3 の周波 数応答関数を観察すると, $10 \mathrm{k} \mathrm{H} \mathrm{z}$ 以下の領域で, $2220 \mathrm{~Hz}$ および $6116 \mathrm{~Hz}$ のはっきりとしたピークがあるこ と, それらのピークよりもやや高い周波数 (3464Hz, $8650 \mathrm{~Hz})$ にもピークが見られることがわかる.

$4 \cdot 2$ 振動モード 図 5 に軸方向長さ $L=66 \mathrm{~mm}$ の場合の 各ピークにおける振動モードを示す。また，図 6 に対応 する解析結果を示す. 図中の $\mathrm{m}$ は円周方向の山数を表し, $\mathrm{n}$ は軸方向の節線数を表す次数である. 例えば, $\mathrm{m}=2$ ， $\mathrm{n}=0$ は, 半径方向に同相で変形する棈円変形モードで あり, $\mathrm{m}=2, \mathrm{n}=1$ は, 棈円変形モードで両端が逆位 相で変形するモードである.
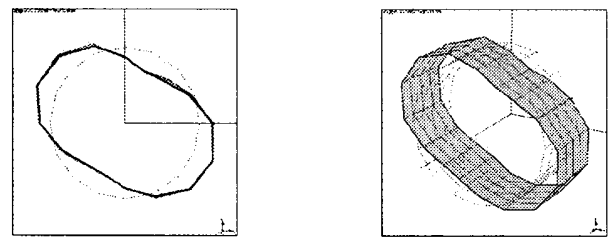

(a) $2219 \mathrm{~Hz}(\mathrm{~m}=2, \mathrm{n}=0)$
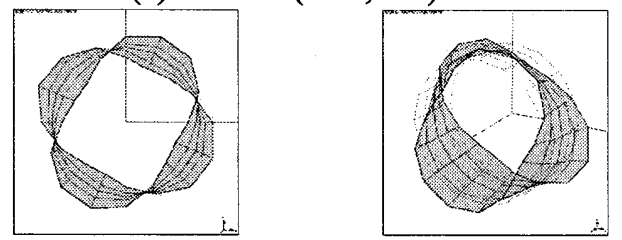

(b) $3462 \mathrm{~Hz}(\mathrm{~m}=2, \mathrm{n}=1)$
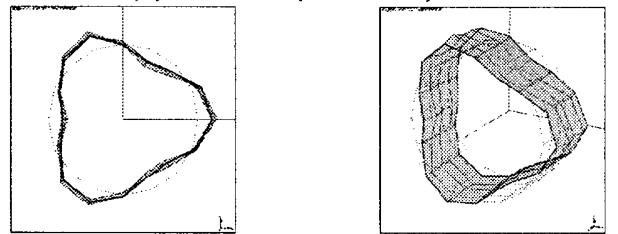

(c) $6067 \mathrm{~Hz}(\mathrm{~m}=3, \mathrm{n}=0)$
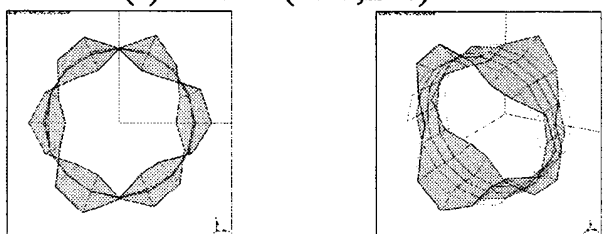

(d) $8643 \mathrm{~Hz}(\mathrm{~m}=3, \mathrm{n}=1)$

Fig. 5 Vibration mode and natural frequency of isotropic thick cylinder (experimental results, $\mathrm{L}=66 \mathrm{~mm}$ )

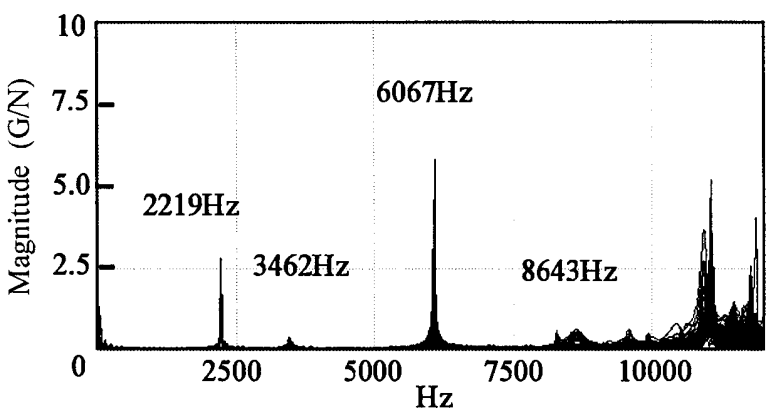

Fig. 3 Frequency response function $(L=66 \mathrm{~mm})$

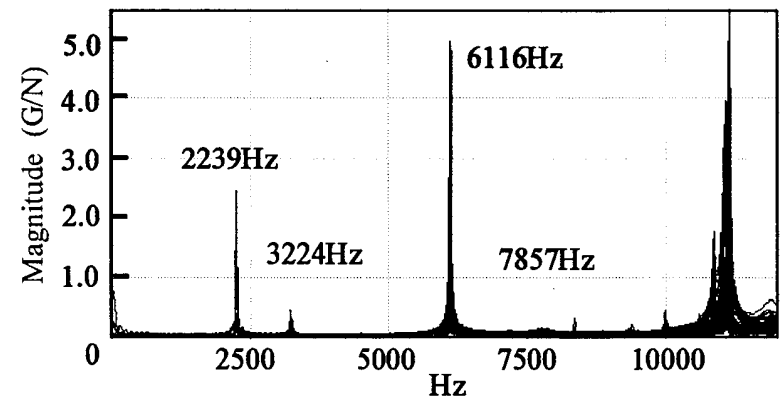

Fig. 4 Frequency response function $(\mathrm{L}=90 \mathrm{~mm})$
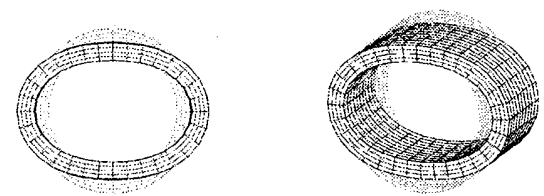

(a) $2263 \mathrm{~Hz}(\mathrm{~m}=2, \mathrm{n}=0)$
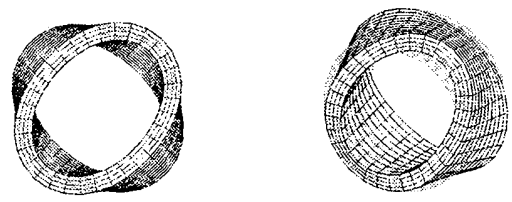

(b) $3489 \mathrm{~Hz}(\mathrm{~m}=2, \mathrm{n}=1)$
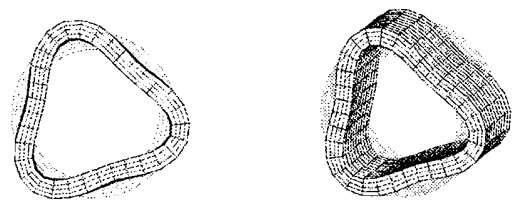

(c) $6224 \mathrm{~Hz}(\mathrm{~m}=3, \mathrm{n}=0)$
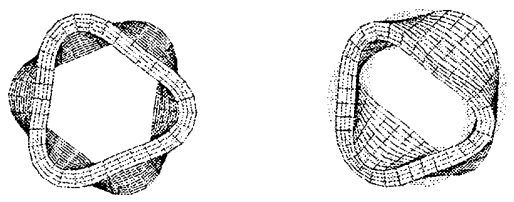

(d) $8550 \mathrm{~Hz}(\mathrm{~m}=3, \mathrm{n}=1)$

Fig. 6 Vibration mode and natural frequency of isotropic thick cylinder (calculated results, $\mathrm{L}=66 \mathrm{~mm}$ ) 
$4 \cdot 3$ 固有振動数に及ぼすモデル長さの影響 図 7 にモ デル長さと固有振動数との関係を示す．図中の括弧内の 数字は，（円周方向の山数 $\mathrm{m}$ ，軸方向の節線数 $\mathrm{n}$ ）を表 している。この図から，打撃試験およびF EM解析で得 られた楕円モード（同相，逆相）および三角形モード

（同相，逆相）の固有振動数は良く一致寸ること，逆相 モードの固有振動数は, 軸長が長くなるほど低下するこ とがわかる.また，固有振動数は誤差 $3 \%$ 以内で一致し た.

\section{$4 \cdot 4$ 固有振動数に及ぼす軸方向縱弹性俰数の影響}

図 8 に 3.2 節で示した軸方向の縦弾性係数が小さい異 方性モデルを用いて解析した固有振動数と縦弾性係数と

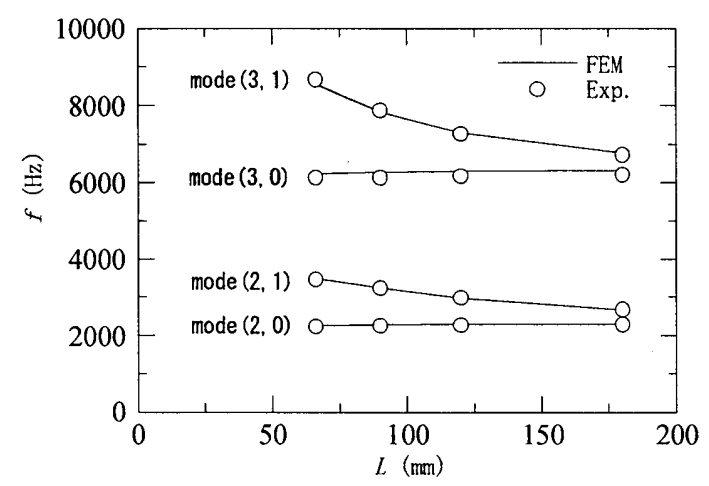

Fig. 7 Effect of cylinder length on natural fr equency of isotropic thick cylinder

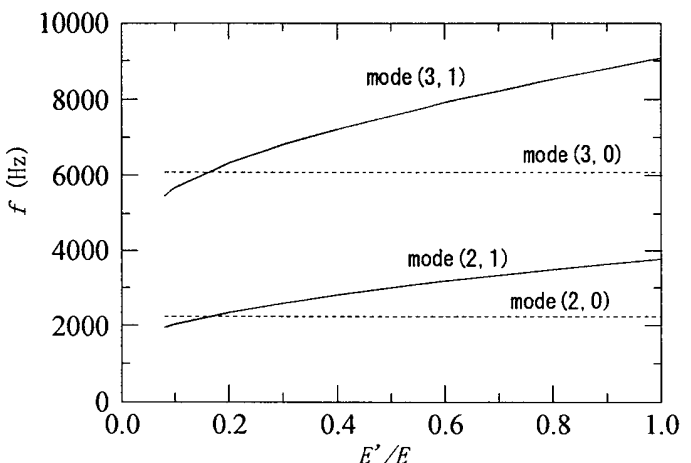

Fig. 8 Effect of Young's modulus on natural frequency of thick cylinder (FEM, L=66mm)

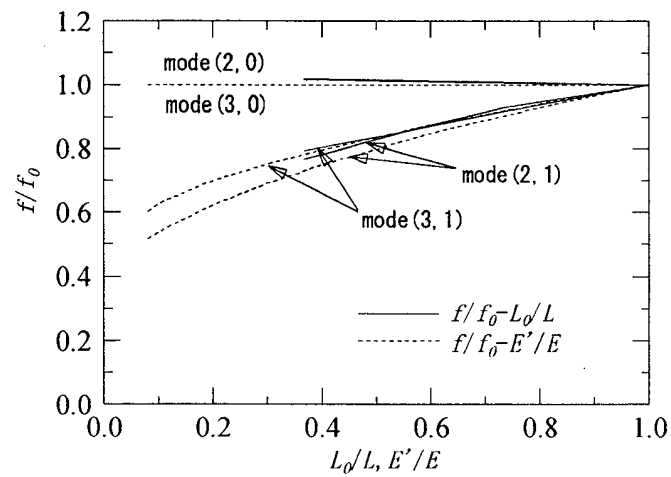

Fig. 9 Effect of cylinder length and Young's modulus on natural frequency of thick cylinder
の関係を示す.この図から, 軸方向の縦弾性係数が小さ くなるに従って, 逆相モード $(\operatorname{mode}(2,1), \operatorname{mode}(3,1))$ の固有振動数が低下していることがわかる。

図 7 および図 8 に示す結果をモデル長さ $L=66 \mathrm{~mm}$, 縦 弾性係数 $E=205.8 \mathrm{Gpa}$ で無次元化して, モデル長さや軸 方向縦弹性係数が固有振動数に及ぼす影響について，あ らためて図 9 に示す.これらの結果から, (1)同相モード の固有振動数はモデル長さや軸方向縦弾性係数にほとん ど影響されず一定であること, (2)逆相モードについては モデル長さが長くなるほど, 軸方向縦弾性係数が小さく なるほど，固有振動数は低下寸ることがわかる.

\section{5. 結}

本研究では, 電動機の電磁騒音低減を目的として, 積 層構造の固定子鉄心の固有振動数を精度良く予測する手 法開発の一睘として, 厚肉円筒の固有振動数や振動モ一 ドについて検討した. 得られた結果を要約して以下に示 す.

（1）等方性の厚肉円筒モデルについて，打撃試験およ びF E M 解析を行い，棈円モード（同相，逆相），三角 形モード (同相, 逆相) の固有振動数を求め, 両者が誤 差 $3 \%$ 以内で一致することを確認した.

（2）厚肉円筒モデルの同相モードの固有振動数は軸方 向長さにはほとんど依存しないが，逆相モードの固有振 動数は，長くなるほど低下寸ることを示した。

（3）厚肉円筒モデルの軸方向の縦弾性係数を変化させた 場合の F EM解析を行い，同相モードの固有振動数は軸方 向の縦弹性係数には依存しないが, 逆相モードの固有振動 数は軸方向の縦弾性係数が小さくなるほど低下することを 示した.

\section{文献}

（1）野田伸一，鈴木功，糸見和信，石橋文徳，森貞明，電動 機固定子鉄心の固有振動数の簡易計算法, 日本機械学会 論文集C編, 60 巻 578 号, 3245-3251，(1994).

（2）野田伸一，リムチーション, 水野末良, 電動機の積層固 定子鉄心に関する固有振動数，日本機械学会 D\&D2008 講演論文集，No.08-14(2008-9)，pp.329.（CD-ROM 論文 集，論文 No.615)

(3) 元恒，林䉷，岩附信行，厚肉円筒の理論振動モ一ト解析， 機械学会論文集 C編, 60 巻 575 号，2233-2240，(1994). 